\title{
ARCHITECTURAL ENGINEERING AS A PROFESSION: REPORT ON RESEARCH LEADING TO A CURRICULUM REVISION
}

\author{
Josifas PARASONIS, Andrej JODKO \\ Department of Architectural Engineering, Faculty of Civil Engineering, Vilnius Gediminas Technical \\ University, Sauletekio al 11, LT-10223 Vilnius, Lithuania
}

Received 12 Feb. 2013; accepted 25 Apr. 2013

\begin{abstract}
Modern design practice, where an architect works with engineers in a large team, lacks optimisation. Improvement of collaboration between the professions of architecture (A) and structural engineering (SE) would result in more efficient structures. Collaboration can be improved by professionals who have training and/or experience in both professions. The fact is proved by the professionals that either were separately trained in each field, or had integrated training in both fields, or successfully practised on the borderline between A and E. The concept of architectural engineering (AE) appeared in the late nineteenth century, and the profession has increasingly been developing from that time on. The Aim of the research is to develop a competence model (CM) for an AE professional, and scientifically substantiate the subject matter of the undergraduate AE programme. The Scope of the study is the analysis of collaboration issues relating to the civil engineering (CE) and A professions, studies on the development of CM, and development of the study programme curriculum. The authors developed a $\mathrm{CM}$ for an $\mathrm{AE}$ professional containing essential competences and courses of the curriculum for training of the modern professional proficient in the development of architectural and structural design projects.
\end{abstract}

Keywords: architectural engineering; competence model; architecture; structural engineering; interdisciplinary undergraduate study programme.

Reference to this paper should be made as follows: Parasonis, J.; Jodko, A. 2013. Architectural engineering as a profession: report on research leading to a curriculum revision, Journal of Civil Engineering and Management 19(5): 738-748. http://dx.doi.org/10.3846/13923730.2013.812980

\section{Introduction}

Modern practice of building construction has undergone significant changes in terms of design and delivery of construction projects. Structures contain a large number of specific and complex architectural and engineering - structural, technological - solutions. Structure and function are inseparable parts of the building design. Therefore, design and construction of structures has to be undertaken by professionals who possess knowledge and experience in both fields, that is architecture and engineering. The benefit of interdisciplinary programmes can be substantiated by the following aspects: interdisciplinary $\mathrm{CE}$ programmes majoring in $\mathrm{A}$, double degree programmes in $\mathrm{A}$ and E (SE) programmes; and programmess of interdisciplinarity presented by building sciences and a number of other sciences.

Competence may be synonymous with certain skills and knowledge required for success in a cetain profession. All professions are composites of knowledge, skills (experience, ability, capability), and behaviour (attitude, personal characteristics, features). The competences presented in this study include common and professional sub-competences. Competences are acquired within a family, at education institutions of all levels, and throughout a professional career. This research focuses on competences and professional skills in the form of theoretical knowledge and practical experience. As employers are usually searching for specialists with specific skills, certain practical skills are essential (e.g. ability to work with specific software). To some extent, graduates of different schools have different skill sets and this is a valuable factor giving some distinction to each individual school. However, in the process of module development, the aim of study programmes is to provide graduates with a particular skill set in order to meet the needs and requirements of a particular profession. All professions have similar common competences, which ensure the demand of graduates on the labour market. These common competences form the basis for professional competences. Until now, there has 
been no research either on the Competence Model (CM) for an $\mathrm{AE}$ professional, or the methodology of its development. A substantiated CM is essential for development of necessary educational modules and courses.

The draft of the undergraduate AE study programme presents both conceptual and actual development, a new teaching and learning framework to meet the curriculum design challenges, and complies with the Regulations.

\section{Methodology}

Comparative analysis was undertaken for evaluation of AE study programmes. The CM was developed following the analysis of relevant reference books
(RBs) (1) on CMs and methodology for their development [57 RBs (the 1st group of RBs)], and (2) on the subject matter, aims of the professions, their essential skills and knowledge, study programme disciplines, and regulations [18 RBs (the 2nd group of RBs)]. Up to now, there has been no common solution for a universal $\mathrm{CM}$ structure that could sufficiently present competencies of various professions. The structure and subject matter of CMs are presented in Tables 1 and 2, and Figure 1 of this study, based on the analysis of the 1st group of RBs. Next, the analysis of the 2nd group of RBs was undertaken in order to develop the subject matter of the $\mathrm{CM}$ for an $\mathrm{AE}$ professional. Cluster, data, content, case study analysis, text analytics, action research methods and personal

Table 1. Analysis of essential competences of Architecture and Technology (denoted in the Table as 'Arch' and 'Tech') sciences

\begin{tabular}{|c|c|c|c|c|c|c|c|c|c|c|c|c|c|c|c|}
\hline \multirow[b]{2}{*}{1} & \multirow[b]{2}{*}{2} & \multirow[b]{2}{*}{3} & \multirow[b]{2}{*}{4} & \multirow[b]{2}{*}{5} & \multirow[b]{2}{*}{6} & \multirow[b]{2}{*}{7} & \multirow[b]{2}{*}{8} & \multirow[b]{2}{*}{9} & \multirow[b]{2}{*}{10} & \multirow[b]{2}{*}{11} & \multirow[b]{2}{*}{12} & \multicolumn{2}{|c|}{ TABLE } & \multirow{2}{*}{$\frac{1}{15}$} & \multirow[b]{2}{*}{16} \\
\hline & & & & & & & & & & & & 13 & 14 & & \\
\hline$\sqrt{5}$ & E & E & $\sqrt{5}$ & F & $\sqrt{7}$ & $\sqrt{5}$ & $\sqrt{7}$ & $\sqrt{5}$ & E & $\sqrt{5}$ & $\sqrt{5}$ & $\sqrt{5}$ & $\nabla$ & -1 & T \\
\hline & 1 & & & & & & & & & & & & Arch & arch draw & 1 \\
\hline & & & 1 & & & & 1 & & & 1 & 1 & & Arch & communication & 4 \\
\hline \multirow[t]{6}{*}{1} & 1 & 1 & 1 & 1 & 1 & 1 & 1 & 1 & 1 & 1 & 1 & 1 & Tech & communication & 13 \\
\hline & & & & & & & & 1 & & 1 & & 1 & Arch & CPD/ teaching/ instruction & 3 \\
\hline & & 1 & & 1 & 1 & & 1 & 1 & 1 & 1 & & 1 & Tech & CPD/ teaching/ instruction & 8 \\
\hline & & & & & 1 & 1 & & & & & & 1 & Arch & creativity & 3 \\
\hline & & & & & 1 & & 1 & & & & & & Tech & creativity & 2 \\
\hline & & & & & & & 1 & 1 & 1 & & & 1 & Arch & crit think/ analytic/ research/ learning & 4 \\
\hline \multirow[t]{3}{*}{1} & 1 & 1 & 1 & 1 & 1 & 1 & 1 & 1 & 1 & & & & Tech & crit think/ analytic/ research/ learning & 10 \\
\hline & & & & 1 & & & & & & & 1 & & Arch & Customer Service & 2 \\
\hline & & 1 & 1 & 1 & & 1 & 1 & 1 & 1 & & & 1 & Tech & design & 8 \\
\hline \multirow[t]{5}{*}{1} & 1 & 1 & 1 & & 1 & 1 & & 1 & 1 & & & 1 & Arch & design/ planning/ site design & 9 \\
\hline & & & & & & & & 1 & & & & 1 & Arch & ethics & 2 \\
\hline & 1 & 1 & & & & 1 & 1 & & 1 & & 1 & 1 & Tech & ethics & 7 \\
\hline & & & & & & & & & & & & 1 & Tech & IT literacy & 1 \\
\hline & & & 1 & & & 1 & & 1 & & 1 & 1 & & Arch & managment/ leadership & 5 \\
\hline \multirow[t]{3}{*}{1} & 1 & 1 & 1 & & 1 & & 1 & 1 & & & 1 & & Tech & managment/ leadership & 8 \\
\hline & & & & & & & 1 & & & 1 & 1 & & Tech & personal & 3 \\
\hline & & 1 & 1 & 1 & 1 & & 1 & 1 & 1 & 1 & & 1 & Arch & $\begin{array}{l}\text { prof practice/ environmental context/ } \\
\text { history }\end{array}$ & 9 \\
\hline \multirow[t]{2}{*}{1} & 1 & 1 & 1 & 1 & & 1 & 1 & 1 & 1 & & 1 & 1 & Tech & $\begin{array}{l}\text { prof practice/ environmental context/ } \\
\text { history/ specializations }\end{array}$ & 11 \\
\hline & & 1 & 1 & 1 & & & & 1 & & & & 1 & Tech & proj/ constr management & 5 \\
\hline 1 & 1 & 1 & & 1 & & & & & & & 1 & & Arch & proj/ pract/ constr management & 5 \\
\hline \multirow[t]{4}{*}{1} & 1 & 1 & & & 1 & & & 1 & & & & & Arch & regulations/ documentation & 5 \\
\hline & & 1 & & & & & 1 & & 1 & & 1 & 1 & Arch & social/ teamwork & 5 \\
\hline & 1 & 1 & & 1 & & 1 & & & 1 & 1 & 1 & 1 & Tech & social/ teamwork & 8 \\
\hline & & 1 & 1 & & 1 & 1 & 1 & 1 & 1 & & 1 & & Arch & tech knowl/ technology & 8 \\
\hline 1 & 1 & 1 & 1 & 1 & & 1 & & 1 & 1 & 1 & 1 & 1 & Tech & tech knowl/ technology/ basic sciences & 11 \\
\hline
\end{tabular}

Note: Columns: 1-13. Number of the RB containing A or Technology related CM (presented below); 14. Science branch of the RB presented below; 15. Competence; 16. Number of times the competence was mentioned in the RB. Following is the list of RBs (presented in Columns 1-13) containing Architecture CM: AACA (2003), AACA (2012), ARB (2012), AIA (2006), Career-Banding for Employees (2008), Council for the Built Environment (2011), Dresden University of Applied Sciences (2012), Florida Agricultural and Technical University (2007), RIAI (2009), University of Sydney (2012), UNC Charlotte Course Catalogs (2012-2013), Virginia Jobs (2012), University of Copenhagen (2012). Following is the list of RBs (presented in Columns 1-13) containing Technology CM: CareerBanding for Employees (2008), Goel (2006), ASCE (2008), Council for the Built Environment (2011), Steghuis et al. (2005), Uhlenbrook and de Jong (2012). 
Table 2. Correlation of the proposed AE programme curriculum with the proposed $\mathrm{CM}$ for an AE professional

\begin{tabular}{|c|c|c|c|c|c|c|c|c|c|c|c|}
\hline 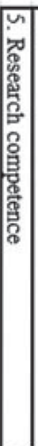 & & & & & 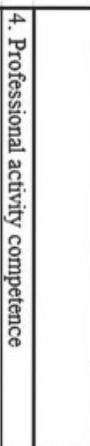 & 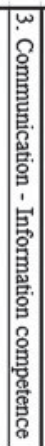 & 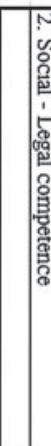 & & & 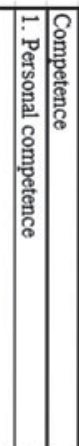 & \\
\hline & 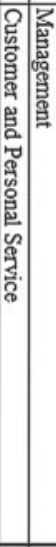 & 寓 & 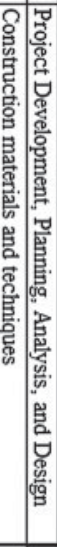 & 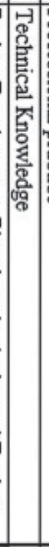 & 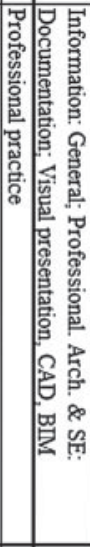 & 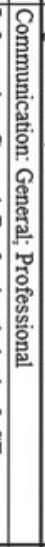 & 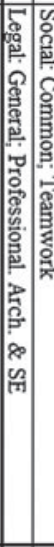 & 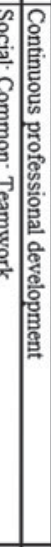 & 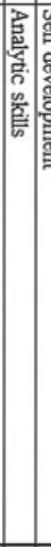 & 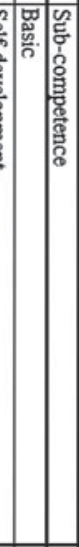 & Course Label \\
\hline & & & & & & & & & & & Architectural design \\
\hline & & & & & & & & & & & Architectural Drawing/Graphics/Artistic expression \\
\hline & & & & & & & & & & & Building codes \\
\hline & & & & & & & & & & & Building engineering physics \\
\hline & & & & & & & & & & & Building engineering systems: Design, Technology \\
\hline & & & & & & & & & & & CAD, B IM; IT programming; Representation Tools \\
\hline & & & & & & & & & & & Communication studies; Public speaking; Foreign language \\
\hline & & & & & & & & & & & Complex project: Architecture; Engineering \\
\hline & & & & & & & & & & & Composition \\
\hline & & & & & & & & & & & Construction engineering, Inspection, Quantity surveying \\
\hline & & & & & & & & & & & Final project: Architecture; Structures; Urban, Landscape design \\
\hline & & & & & & & & & & & Free Elective \\
\hline & & & & & & & & & & & Geodesy \\
\hline & & & & & & & & & & & History of building construction, architecture, arts \\
\hline & & & & & & & & & & & Humanities; Social sciences \\
\hline & & & & & & & & & & & Industrial training: Architecture; Structures \\
\hline & & & & & & & & & & & Mathematics \\
\hline & & & & & & & & & & & Natural sciences \\
\hline & & & & & & & & & & & Physical Training \\
\hline & & & & & & & & & & & Professional language \\
\hline & & & & & & & & & & & Professional practice \\
\hline & & & & & & & & & & & Project Management \\
\hline & & & & & & & & & & & Structural analysis and design \\
\hline & & & & & & & & & & & Training/ Practice: Surveying \\
\hline
\end{tabular}

experience were elaborated during the study. Following acronyms are used in the article: architecture (A), structural engineering (SE), architectural engineering (AE), competence model (CM), civil engineering (CE), reference books (RBs), Vilnius Gediminas Technical University (VGTU), university (U).

\section{Collaboration between architecture and engineering}

No separation between the fields of Architecture (A) and Engineering (E) existed until the mid-eighteenth century, which emerged with establishment of engineering schools. Since then, the relationship between these two professions has evolved from their complete 


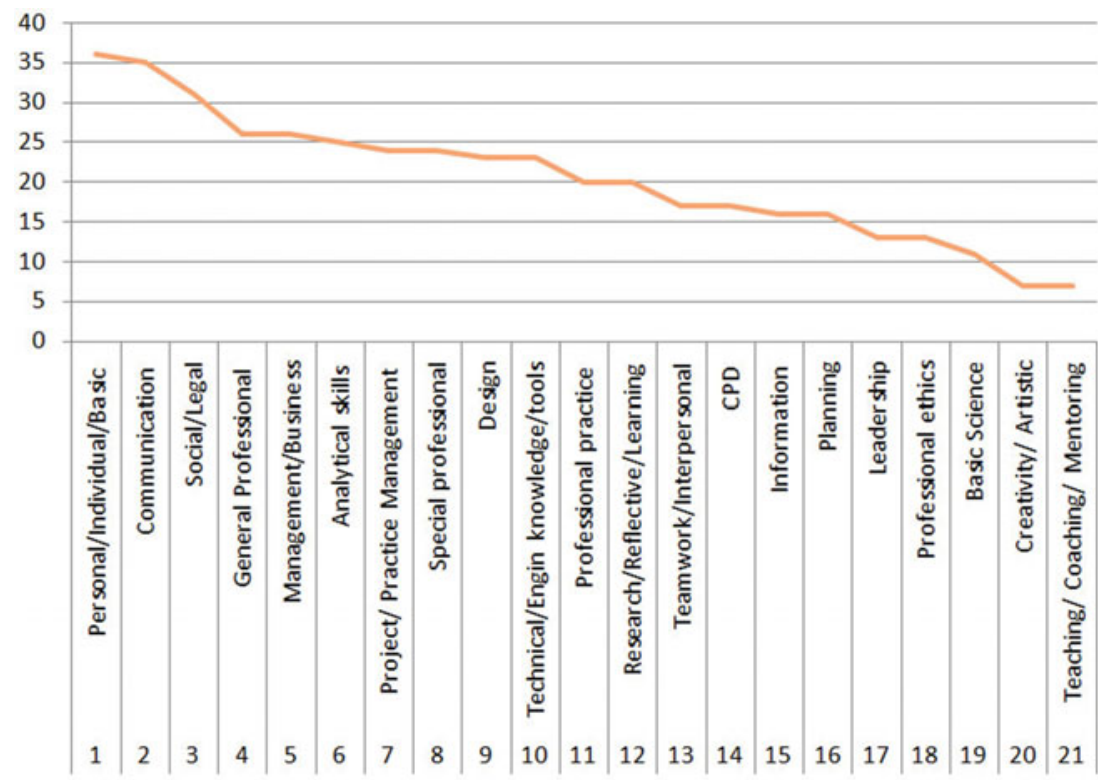

Fig. 1. Number of CMs that mention particular competences. Essential competences/competence groups ( $X$-axis); number of times mentioned ( $Y$-axis)

separation in the nineteenth century to the intense collaboration of today (Larena 2006). Interaction between the professions can be characterised by three forms: separate activity, interpenetration of both fields, and close collaboration.

During the entire process of building project development, an architect seems to be in a position similar to an orchestra conductor and composer. In times of urgency and war, engineering becomes predominant; while in times of peace, plenty, luxury, and affluence architecture comes to the fore (Saint 2008). As generic knowledge in engineering (E) is not sufficient for architects to undertake structural calculations, the expertise of engineers becomes indispensable. Even an annual course on building structures is insufficient for an architect to design the structure of even a small building. If architects were to work without engineers, erroneous and unsound results could follow. Furthermore, engineers make a considerable input into modern construction in terms of finance and technology. As buildings become more complex, the technical part of the design has devolved more and more upon the multidiscipline engineers (Urban Realm 2011). Even if architectural solutions suggested by engineers were 'utilitarian and/or ugly', people would still live in durable, safe and healthy buildings.

Over the period of 200 years, construction professionals, differing only in title and performing the same services, eventually began to perform different services in the same project (Saint 2008). Services of engineers and architects participating in projects ranged from 'minimal architectural advice whatsoever', through to 'architect as an artist' with the engineer as a helpmate or servant (Holgate 1992).
Both professions have a number of things in common, and a number of common courses in their study programmes. In some designs, the structure of a building is the main aesthetical accent, often termed 'structural art'.

There are architects who have good capacities in structural engineering and engineers who have good knowledge of architecture. There have been or are professionals that graduated from one, both, or integrated programmes (Dieste, Nervi, Candela, Isler, Fuller, Le Ricolais, Otto and others [the authors have identified more than 40 prominent professionals in this category]), who acted or are still acting both as architect and engineer, ignoring professional demarcations and blurring the professional borders. In the collaboration and search for a successful design, the disciplines have actually merged into one another.

Both professionals are essential for modern construction projects. All possible factors - functional needs of clients, regulatory impacts, technological advances, the use of new materials, innovations in methods and techniques, computerisation of design and construction and and so on - promote a more intense dialogue and collaboration to bring the two professions closer together. An architect and an engineer need each other in order to develop something that neither could produce alone. The necessity of intense collaboration is proved by: (1) development of the fields, its meaning, perception, and practice; (2) training, practice issues, and current trends of $\mathrm{A}, \mathrm{E}$, and architectural engineering (AE); (3) differences in the training and practice of $\mathrm{A}$ and structural engineering (SE) (Jodko 2012); (4) presence of the interdisciplinary CE study programmes majoring in $\mathrm{A}$, and double degree in A \& civil engineering (CE) or 
A \& SE study programmes; (5) pro arguments for the meaningfulness of interdisciplinary study are presented by various sciences, fields of human activity and the construction science itself.

Similar to the mediaeval master builder role, it is proposed that architectural and structural engineering responsibilities should no longer be strictly separated, but rather collaboratively integrated (Herr et al. 2012). The division between the $\mathrm{A}$ and $\mathrm{E}$ that took place in the nineteenth century has proved to be wrong for the design and construction process. The lack of intense collaboration hinders the development of advanced structural and technological construction projects.

\section{Architectural engineering}

Architectural engineering (AE) is a profession that focuses on close interaction between architecture (A) and engineering (E) throughout the building development process. Failure to ensure intense collaboration between the professions and resolve tasks in an integrated way may result in a danger that a number of tools would remain unused. The design of a structure is an output of architectural tasks, the structural system of a building, selection and calculations of the structural model, its engineering systems, technical and economic efficiency. The essence of architectural and engineering design is the search for an optimal structural solution based on architectural function (and aesthetics). The training of AE professionals (as they are perceived by the authors of this paper) helps to diminish the increasing gap between $\mathrm{A}$ and $\mathrm{E}$, and guarantees better quality of construction projects. An AE professional, both an architect and engineer, is obliged to act as the leader of a project team due to the greatest possessed knowledge necessary to perceive and produce architectural and engineering design.

Today, there are more than $60 \mathrm{AE}$ university study programmes of various degree combinations around the world. The undergraduate AE study programme at Vilnius Gediminas Technical University (VGTU) was established in 2000. Training of AE professionals in Lithuania is based on National Regulations (Common Requirements for the Educational Field of Technological Science 2005), and aims to retain sufficient balance and close collaboration between the fields of architecture and structural engineering in the study programme.

The A study programme emphasises design and artistic approach with support from E knowledge, concentrates on the functional/spatial layout and aesthetical aspects of buildings. The AE study programme contains $\mathrm{E}$ instruction and orientation, emphasises E systems and aspects of the building design and the construction process. The study programme combines scientific and pragmatic aspects and is based on a calculated approach. The aim of the
AE study programme is to provide graduates with knowledge, skills and experience to perform both architectural and structural design of the project.

The perception of AE by the authors is based on a comparative analysis of the subject matter of the undergraduate AE programme (Jodko, Parasonis 2012), and analysis of AE training and practice issues. The analysis presents a comparison of $33 \mathrm{AE}$ undergraduate study programmes considering a number of aspects. Block $\mathrm{C}$ (specialisation courses or the adjacent study branch courses of the study programme) courses in the analysis were divided into $\mathrm{A}$ and $\mathrm{E}$ courses. Results of the analysis show that the VGTU AE study programme is among the programmes that have the greatest balance of $\mathrm{A}$ and $\mathrm{E}$ course relative credit values in block $\mathrm{C}$. There are only $7 \mathrm{AE}$ programmes in the world that have a bias of up to $5 \%$ into either side. Following are the universities and their relative credit values for architectural courses: North Carolina University (U) - 45.95; Chung-Ang U 46.15; VGTU - 47.14; Hanyang U - 47.37; Penn State U - 50.00; Drexel U - 52.34; Oklahoma State $\mathrm{U}-54.93$.

\section{Competence model}

Development of the architectural engineering (AE) study programme and curriculum design at VGTU in 2000 was based on the analysis of subject matter of the undergraduate architecture (A) and civil engineering (CE) [structural engineering (SE)] study programmes of that time. The study programme was empirically updated a number of times. The further research is aimed at revision of the VGTU undergraduate AE study programme. In order to develop scientifically substantiated subject matter for the study programme, a competence model (CM) had to be developed for an AE professional, comprising the essential knowledge and skills of an architect and structural engineer. In order to develop the $\mathrm{CM}$, in addition to personal experience, an analysis was made of a number of reference books (RBs) on CM structure and subject matter of various science branches; study cycle description (Descriptor of Study Cycles 2011); studies and regulations on the essential competences of and services provided by an architect and structural engineer; differences in the training and practice of A and SE (Jodko 2012); needs of the professions.

\subsection{Structure of the competence model}

Data from 57 reference books (RBs) on the competence models (CMs) of 8 sciences or types were analysed, including: Technology (13 RBs), Architecture (13 RBs), Sociology (7 RBs), Humanities (2 RBs), Biomedicine (1 RBs) science branch competence models, methodologies on CM development (10 RBs), 
graduate competences (8 RBs), employee competences (2 RBs).

The RBs reveal different structure of the CMs, quantity of competences and sub-competences. There are $11 \mathrm{CMs}$ that present 2 to 4 competences with 7 to 41 sub-competences. There are $46 \mathrm{CMs}$ with 3 to 38 competences without further division. Among the above mentioned $46 \mathrm{CMs}$, there are 18 with 3 to 4 competences containing 3 or more concepts explaining the competence. Other $28 \mathrm{CMs}$ present 3 to 38 competences without further description. For instance, architecture CMs contain 3 to 12 competences and one $\mathrm{CM}$ contains 2 competences and 11 sub-competences; there are two Technology science CMs containing 3 and 4 competences with sub-competences, and other CMs contain 4 to 16 competences.

Various competences found in other researches are included in the competences of the CM proposed in this study [presented below in the chapter 3.2.]. In the proposed CM, competences (Fig. 1) No. 1, 6, 14 and 20 are included into the 1st competence; competences No. 3 and 13 are included in the 2nd competence; competences No. 2 and 15 are included in the 3rd competence; competences No. 4, 5, 7, 8, 9, $10,11,16,17,18$ and 19 are included in the 4th competence; and competence No. 12 is included in the 5th competency. Competencies that were mentioned only in a few RBs were added to other related competences forming competence groups separately recognisable by slashes between the concepts. Figure 1 presents 21 competences/competence groups.

As the research is focused on an interdisciplinary AE study programme, CMs related to A and Technology (Tech) sciences were analysed, and the competences mentioned in them were presented in Table 1. Twenty-seven overall competences [14 of them in A competence models (CMs)] were identified, and the same 11 competences were mentioned in CMs of both $\mathrm{A}$ and Tech sciences. The competences were mentioned in CMs from 1 to 13 times.

\subsection{Competence model for the architectural engineering professional}

Once the 1st group of reference books (RBs) was analysed, authors of the study developed the competency model $(\mathrm{CM})$ for the architectural engineering (AE) professional. Due to the fact that various researchers mentioned similar competences as essential, these competences were included in the proposed $\mathrm{CM}$. These CMs influenced the structure, and labels of the competences and sub-competences. The proposed $\mathrm{CM}$ for an $\mathrm{AE}$ professional complies with the requirements, specific skills and knowledge listed in the study cycle description.
In some cases, competences depicted in Figure 1 and Table 2 are generic competences (e.g. personal, communication - information, etc.), in other cases sub-competences (e.g. management, professional practice, etc.), and yet other cases - skills or knowledge of a particular competence (e.g. architectural drawing, information technology (IT) literacy, etc.) of a proposed CM.

Skills and knowledge included in the $\mathrm{CM}$ were collected mostly from the 2 nd group of RBs. These RBs discuss the desired skill set for architects and structural engineers, and issues related to the training and practice of the professions. RBs include: several articles focusing on the competences of the architect (Oklahoma State University 2010; AIA 2011; Architectural Engineering 2013; North Carolina State University 2013), IT architect (Cutolo 2009), engineer (Uttarakhand Board of Technical Education 2009), structural engineer (Association of Professional Engineers and Geoscientists of British Columbia 2011; Graduate Structural Engineer Responsibilities and Duties 2012), and architectural engineer (California Polytechnic State University 2012; Missouri University of Science and Technology 2012; North Carolina State University 2013). Other studies focus on architectural practice issues (Prince-Ramus 2009; Friedman 2010), the history of architecture (Bransford et al. 2000), engineering practice issues, engineering education (Mitcham 2009; Fries et al. 2010; Rangel, Gabriel 2010), and the collaboration between architects and engineers (Charleson, Pirie 2009). All of the above-mentioned studies also present the common competences of an architectural engineering (AE) professional.

The competence model $(\mathrm{CM})$ of an AE professional proposed by the authors contains 5 competences (personal, social-legal, communicationinformation, professional activity, and research competences) and 20 sub-competences (Table 2). The CM includes: professional sub-competences of an $\mathrm{AE}$ professional; common sub-competences inherent to members of all building professions; basic and generic (contrary to professional) sub-competences depicting knowledge and skills common to all individuals. The subject matter of chapters ' $A$ ' and ' $S E$ ' represents separate particular competences of both professions.

All competences, except for the Professional Activity, represent both Generic and Common/ Professional sub-competences. Except for the Project Development, Planning, Analysis, and Design subcompetences representing separate competences for both professions; the 2nd, 3rd, 4th and 5th competences represent skills and knowledge essential to both (A and SE) professions. First three competences can be used by any building profession in the relevant $\mathrm{CM}$. The fact that the grouping of knowledge and skills in the competences is provisory should be kept in mind, 
because a number of skills and areas of knowledge can belong to one or another competence.

The following is the proposed CM.

1. Personal competence:

Basic. Physical, mental and moral health; efficient completion of assignments; personal and professional motivation. Self-development. Self-development, its trends; evaluation of personal or joint activities; responsibility, autonomy, perseverance. Analytical skills. Working consistently at an abstract level; analytical approach, critical thinking; problem simulation, alternatives assessment, solution proposals; insight, the ability to see the 'big picture'. Continuous Professional Development (CPD): generic: planning, commitment to and participation in continuous professional education; technical and non-technical skills development throughout the career. Professional. A. \& SE. Fulfil CPD requirements in countries where they are specified; attend conferences on various profession-related subjects.

\section{Social-legal competence:}

Social

Common. Evolution and trends of nature, society, business environment; non-professional sustainable intercultural and interdisciplinary areas (academic, recreational, creative); preservation of national culture. Teamwork. Methods, organisation of, participation in governmental organisations, interdisciplinary activities; teamwork climate/morale; conflicting parties reconciliation; consideration of the environmental effects of activities.

\section{Legal}

Generic. Human rights, laws, governmental regulations; strategies for the protection of people, data. Professional. $A \& S E$. Industry, governmental and public contracts on project-related matters; work in compliance with all health, safety, and legal codes and regulations; analysis of regulations.

\section{Communication-information competence: Communication}

Generic. Knowledge of native and foreign language; business writing; comprehension of information presented; public speaking; mastery of negotiation. Professional. Professional language; provision of information to public bodies, clients, co-workers; persuasively articulated services, technologies, and their business value to customers; preparing documents and explaining projects.

\section{Information}

Generic. Documentation, communication tools, computer hardware and software; develop new programmes for special purposes. Professional. $A \&$ $S E$ : documentation. Contract documents, reporting, business letters, work-related documents, technical project documentation. Visual presentation, CAD, $B I M$. Creative imagination; depict ideas, conceptual diagrams in drawings and reports; principles of technical plans, and scale model production; design techniques, tools (using e.g. Auto Cad, SketchUp, STAAD, Revit, etc.); video animation; testing, calculation software; computer simulations of structures.

\section{Professional activity competence:}

Professional practice

Common: history of the profession, trends; disciplines within a profession; sustainable professional activities; professional ethics; determining specific project issues at the time of the initial agreement. Specialisation. Expertise/focus on a particular professional area (e.g. architecture, engineering, construction, facility management, models, simulations, and training), for further practice/research.

Technical knowledge

$A \& S E$. Mathematics, mechanics, applied and engineering sciences; system components; building construction, and maintenance tools and equipment; production of various goods, and services.

Project analysis, development, planning, and design

$A \& S E$. Design and renovation; design climates; consider requirements for function, strength, form, economy, budget restraints, resources, environment, technology; site analysis, geotechnical issues, provisional structures; feasibility, building performance optimisation: energy auditing, advanced computational modelling; specifications of equipment, construction, and maintenance of structures.

$A$. Architectural design, programming/planning and development; creative imagination, and psychology; determine the client needs; evaluate, translate building requirements and design solutions proposed by consulting design professionals. $S E$. Design structural components and systems; ability to design these for different materials; develop and interpret shop fabrication documents; perform, evaluate, organise, review, and ensure accuracy and completeness in all structural design calculations; dynamic effects evaluation; assess extreme loads; develop structural design standards for projects; structural material specifications and recommendations; prepare demolition documents.

Construction materials and techniques

$A \& S E$. Knowledge of substructure to superstructure construction techniques and equipment, maintenance operations; manufacturing processes, their properties, laboratory/field testing, and costs of construction materials.

\section{Inspection}

$A \& S E$. Inspection and review of construction progress and structural design; common defects, alterations and remedial works; shop drawings and other submittals review for conformance with contract documents. 


\section{Management}

Generic. management, leadership experience, business strategy, and consulting; marketing, production methods, coordination, modelling, and resource allocation; control the level of productivity and success; Team management. Team building (also during the activity) and supervision; motivating, planning and coordinating the activities of people; time management, keeping the project within budget and on schedule; identifying the best people for the job. Professional. $A \& S E$. Practice/facility/project/labour/ construction financial management, contract administration; review, analyse and evaluate bids, submitted tenders, cost estimates, bills of quantities for design, materials; writing and managing contracts, procurement processes.

\section{Customer and personal service}

Organising consumer and personal services; assessing customer needs and satisfaction, proposing solutions; sales ability.

\section{Research competence:}

Common. Conduct research, have a scientific investigative attitude; make hypotheses, simulate processes and events; submit articles to scientific journals and magazines, write books, and make conference presentations; innovate in the selected research area; identify, analyse, evaluate and objectively organise information and results.

\section{Draft of the undergraduate architectural engineering study programme}

Considering the competence model (CM) for an architectural engineering (AE) professional presented above, the draft of Vilnius Gediminas Technical University (VGTU) undergraduate AE programme was developed. According to Reglamentas the programme belongs to the civil engineering science branch, and was developed in compliance with Reglamentas. This is not exclusively an empirical study. Authors endeavour to implement interdisciplinary teaching of the two salient fields of the construction industry, and propose a carefully formulated curriculum.

The aim of the programme is to provide graduates with:

- fundamental attitude towards overall construction investment process; ability to prove the benefits of the design concept, conduct feasibility studies based on the training in architectural and engineering disciplines;

- ability to integrate design of all building systems into the project; ability to communicate with different professionals and society in performing professional services;

- integrated knowledge of architecture (A) and civil engineering (CE (structural (SE) devel- oped by building sciences; knowledge of state of the art technologies, and construction investment process development;

- theoretical knowledge and experience to apply the knowledge substantiating efficient architectural and structural solutions, and applying innovative IT tools and methods;

- theoretical knowledge and experience to coordinate design development of all building systems, work in construction industry, oversee the construction development, and perform the project maintenance;

- ability to become self-directed, independent learners by the time of graduation, to update their professional knowledge;

- apply in their practical activities achievements of science and technology, complying with the requirements of the construction industry profession;

- personal, social, special skills in order to train efficient professionals for design and construction companies, governmental institutions; ability to conduct and apply research.

Graduates of the programme practicing structural engineering will be skilled to deal with architectural issues, and those practicing architecture will be skilled to deal with engineering issues. Training of such professionals presumes both the improvement of the project quality, and the increase in the speed of project development.

As the programme includes the courses dedicated to other building systems needed for the overall functional structure, graduates of the programme, after gaining some experience, would be capable of leading a project team in a more professional manner rather than members of other building professions.

The following guiding principles were set for the interdisciplinary programme development: (1) comprehensive coverage of both areas; (2) commonality of background; (3) analysis before synthesis. The following contextual variables were kept in mind in the curriculum development: needs of the industry, challenge in the curriculum, goal achievement, and interplay of these concepts (Yeung et al. 2012). Authors summarised valuable points of the programme to-bedeveloped, and used them as a benchmark for working it out.

\section{Courses}

Most courses of the undergraduate engineering programme of VGTU are stipulated by Descriptor of Study Cycles (2011); they are divided into block A (General University), block B [courses of Technological Science Branch (core of the study programme)], and block $\mathrm{C}$ (specialisation courses or the adjacent study branch courses of the study programme). Descriptor of Study Cycles (2011) prescribes a 
compulsory number of ECTS (European Credit Transfer and Accumulation System) credits for each block courses: 15 for block A, 165 for block B and 65 for block C. The programme is modularised, and individual modules address the criteria of Common requirements for the educational field of Technological Science (2005). Thus, the programme includes 56 prescribed modules ( 7 in each semester) (linked into the course groups presented in Table 2), and several zero credit courses.

In the process of programme development and deciding on what to teach, authors listed courses essential for the training of particular skills/knowledge presented in competence model $(\mathrm{CM})$ for an $\mathrm{AE}$ professional. Underlying factors when choosing courses of the proposed study programme were the analyses of: requirements of national regulations; skill-set defined by the $\mathrm{CM}$ for an AE professional; curricula of 33 undergraduate AE programmes currently present around the globe (Jodko, Parasonis 2012); curricula of $11 \mathrm{~A}$ and $11 \mathrm{CE}$ undergraduate programmes of five continents; relevant educational objectives; needs of the professions; personal experience.

Suggestions made by other authors (Mitcham 2009; Rangel, Gabriel 2010) in the studies on education methodologies, curriculum design and assessment were considered.

Considering national regulations, it was important to choose not only what is best to teach, but also in what order. When organising the courses in the curriculum, such factors as course duration, and such aspects as concrete to abstract, whole to part, simple to complex, were considered. For instance, courses in the programme are introduced starting from basic and generic and progressing to specialise (the reason why basic speciality history and theory courses are being taught during the first year); several curriculum (e.g. mathematics, architectural and structural design) courses are organised in complexity levels.

\section{Discussion and conclusions}

The research presents the first competence model (CM) for the architectural engineering (AE) professional and courses necessary for training required competences. The proposed CM may serve as a tool for defining the skills and knowledge of programme graduates, and as a tool for choosing the programme modules. The proposed CM suggests implementing a broad variety of study courses considering their duration and the number of subjects. The structure of the proposed CM could be used in CM development for other professions. Only the subject matter of professional sub-competences and the subject matter of the 4th competence would differ depending on the profession.
Opinions of practicing employers and professionals (professionals of this type rarely present their opinions in highly ranked scientific journals) would be valuable in regard to the skills of the graduates, emphasising the skills that have been poorly developed, and those that the graduates lack completely. The great number of competences presented proves that a professional cannot acquire all necessary skills at a university, and that lifelong learning is more of a necessity than an option.

An attained compliance of the proposed curriculum with Reglamentas is presented in the study. The results can be of benefit for the development of the interdisciplinary programme, and also for bridging the gap between the professions. However, the gap would disappear if the training in both professions was integrated.

The appearance and development of architectural engineering (AE) in the construction field has been stimulated by the need to optimise construction project development, and improve the sometimesinefficient collaboration between an architect and a structural engineer. The essential AE professional skills and knowledge, which compose the proposed competence model $(\mathrm{CM})$ presented in this paper, are based on the analysis of the professional practice of architects and structural engineers, and on the analysis of the competence models for professionals in various science branches.

The literature analysis reveals that $\mathrm{CMs}$ of various science branches have many things in common (Fig. 1). The proposed CM for an AE professional could be the foundation for development of AE undergraduate study programmes. In the process of programme development, the following things that have not been discussed in this research should be kept in mind: sequence of courses, duration and interaction of the courses, training methods, and application of efficient competency evaluation methodologies.

The results will help CM developers, academic and other researchers, to bridge the gap between essential skills and curriculum, as well as the gap between the professions, and will become a springboard for improving AE CM. The proposed CM presents the required skill set of an AE professional, and serves as a foundation for the development of the curriculum for an undergraduate AE study programme. The CM presents succinct skill-set for an AE professional. This is due to the fact that curriculum of an undergraduate AE programme can contain a limited quantity of courses, and not all skills of AE professional can be acquired at the university.

The paper presented essential courses/course groups of the proposed study programme curriculum for training in the competences linked with the CM. 
Further research should aim ensuring that graduates would not lack required skills and would be better prepared to face practical challenges.

\section{References}

AACA. 2003. The national competency standards in architecture [online], [cited 11 February 2013]. Available from Internet: http://www.aaca.org.au/NCSA01.PDF.

AACA. 2012. Architectural practice examination, 7 mandatory prescribed elements of competency [online], [cited 11 February 2013]. Available from Internet: http://www.aaca.org.au/wp-content/uploads/2012/07/ APE-on-line-Brief-July-2012.pdf.

AIA. 2006. An architect's residential services [online], [cited 11 February 2013]. Available from Internet: http://howdesignworks.aia.org/casestudy-architectsser vices.asp.

AIA. 2011. Senior Architect (AIA) - architectural engineering [online], [cited 11 February 2013]. Available from Internet:

http://up.theladders.com/Senior-Architect-AIA---Ar chitectural-Engineering $\mid$ Midwest $\mid$ 1996227? $\mathrm{x}=\mathrm{q}$.

Architects Registration Board (ARB). 2012. Guidelines for maintaining competence [online], [cited 11 February 2013]. Available from Internet:

http://www.arb.org.uk/publications/guidance/maintain ing_competence.php.

Architectural Engineering. 2013. Architectural Engineering overview [online], [cited 11 February 2013]. Available from Internet:

http://www.careercornerstone.org/architectural/archen gprep.htm.

ASCE. 2008. Civil engineering body of knowledge for the 21st century preparing the civil engineer for the future [online], [cited 11 February 2013]. Available from Internet: http://www.asce.org/uploadedFiles/Leadership_Train ing_-_New/BOK2E_\%28ASCE_2008\%29_ebook.pdf.

Association of Professional Engineers and Geoscientists of British Columbia. 2011. Guidelines of professional structural engineering services for Part 3 Building Projects [online], [cited 11 February 2013]. Available from Internet:

http://www.apeg.bc.ca/ppractice/documents/ppguideli nes/Guidelines_for_Professional_Structural_Engineer ing_Services_for_Part_3_Building_Projects.pdf.

Bransford, J.; Brown, A.; Cocking, R. (Eds.). 2000. How people learn. Brain, mind, experience, and school. Washington, DC, USA: National Academy Press. 384 p.

California Polytechnic State University. 2012. Program description [online], [cited 11 February 2013]. Available from Internet:

http://www.arce.calpoly.edu/programs/undergraduate.

Career-Banding for Employees. 2008. Competency profiles. [online], [cited 11 February 2013]. Available from Internet:

http://www.osp.state.nc.us/CareerBanding/pro files.htm.

Charleson, A. W.; Pirie, S. 2009. An investigation of structural engineer-architect collaboration, SESOC Journal 22(1): 97-104.
Common requirements for the educational field of Technological Science. 2005. Valstybès žinios, No 59-2079. (in Lithuanian).

Council for the Built Environment. 2011. Policy proposals for the new SGB policy framework for the development of built environment qualifications in South Africa. First Draft. January 2011 [online], [cited 11 February 2013]. Available from Internet: http://www.cbe.org.za/PDF/SGB\%20policy $\% 20$ propo sals $\% 201$ st $\% 20$ draft $\% 20$ FINAL.pdf.

Cutolo, L. 2009. The Architect's competencies [online]. [cited 11 February 2013]. Available from Internet:

http://it.toolbox.com/blogs/cooking-ea/the-architectscompetencies-33628.

Descriptor of Study Cycles. 2011. Approved by Order No. V-2212 of 21 November, 2011, of the Minister of Education and Science of the Republic of Lithuania. 9 p. (in Lithuanian)

Dresden University of Applied Sciences. 2012. Studying architecture [online], [cited 11 February 2013]. Available from Internet:

http://www.htw-dresden.de/en/faculty-of-civil-enginee ring-architecture/architecture/studying-architecture.html.

Florida Agricultural and Technical University. 2007. Architecture 2007-2008. Academic Learning Compact [online], [cited 11 February 2013]. Available from Internet: http://famusoa.net/ALCs/B_Arch.pdf.

Friedman, A. 2010. Rethinking housing education in architecture schools, International Journal of Architectural Research 4(2-3): 54-60.

Fries, R.; Cross, B.; Morgan, S. 2010. Utilizing external internships in a Civil Engineering Capstone Design Course [online], [cited 11 February 2013]. Available from Internet:

http://www.siue.edu/ rfries/2011-TRB-Senior\%20Des ign-published.pdf.

Goel, S. 2006. Competency focused engineering education with reference to IT related disciplines: Is the Indian system ready for transformation?, Journal of Information Technology Education 5: 27-52.

Graduate Structural Engineer Reponsibilities and Duties. 2012. List of Graduate Structural Engineer Reponsibilities and Duties [online], [cited 11 February 2013]. Available from Internet:

http://www.greatsampleresume.com/Job-Responsibiliti es/Graduate-Structural-Engineer-Reponsibilities.html

Herr, C. M.; Fischer, T.; Millard, S.; Brown, A. 2012. Form and formalism: on the future role of structural design in architectural education in China, Advanced Materials Research 450-451: 257-262. doi:10.4028/www.scientific.net/AMR.450-451.257

Holgate, A. 1992. Aesthetics of built form. Oxford: Oxford University Press. 289 p.

Jodko, A. 2012. Architektūra ir konstrukcijos. Studijų ir praktinès veiklos skirtumai [Architecture and Structural Engineering. The difference between training and professional practice in the fields], in Proc. of the 15th Conference for Junior Researchers "Science - Future of Lithuania", Section "Construction”, 22-24 March, 2012, Vilnius, Lithuania. $6 \mathrm{p}$. 
Jodko, A.; Parasonis, J. 2012. Curricula of the world architectural engineering undergraduate programs, International Journal of Engineering Education 28(3): 633-641.

Larena, A. B. 2006. Origin of the collaboration between engineers and architects in Great Britain in the thirties [online], [cited 11 February 2013]. Available from Internet:

http://www.arct.cam.ac.uk/personal-page/james/ichs/ Vol\%201\%20357-378\%20Bernabeu.pdf.

Missouri University of Science and Technology. 2012. Architectural Engineering [online]. [cited 11 February 2013]. Available from Internet:

http://civil.mst.edu/undergraduateprograms/architec turalengineering.html.

Mitcham, C. 2009. A historico-ethical perspective on engineering education: from use and convenience to policy engagement, Engineering Studies 1(1): 35-53. http://dx.doi.org/10.1080/19378620902725166

North Carolina State University. 2013. Architect competency profile, n.d. [online], [cited 11 February 2013]. Available from Internet:

http://www.doc.state.nc.us/docper/Classification/Engin eering/Architect-cp.pdf.

Oklahoma State University. 2010. Architecture program report. Bachelor of Architecture degree program, September 1, 2010 [online], Oklahoma State University, School of Architecture. [cited 11 February 2013]. Available from Internet:

http://architecture.ceat.okstate.edu/SOA $\% 20 \mathrm{NAAB} \%$ 20APR_\%202011.pdf.

Prince-Ramus, J. 2009. Building a theater that remakes itself [online], [cited 11 February 2013]. Available from Internet: http://architecturelab.net/2010/01/28/joshua-prince-ra mus-building-a-theater-that-remakes-itself/.

Rangel, D.; Gabriel, J. 2010. Engineering design educational model: from skills to objectives [online], [cited 11 February 2013]. Available from Internet: http://gradworks.umi.com/14/79/1479550.html.

RIAI. 2009. Standard of knowledge, skill and competence for practice as an architect [online], [cited 11 February 2013]. Available from Internet:

http://www.riai.ie/uploads/files/RIAI_Standard_Know ledge_Skill_Competence_Architect.pdf.

Saint, A. 2008. Architect and engineer: a study in sibling rivalry. Yale: Yale University Press. 530 p.
Steghuis, C.; Voermans, K.; Wieringa, R. 2005. Competencies of the ICT architect. Netherlands Architecture Forum, Enschede, 8th July 2005 [online], [cited 11 February 2013]. Available from Internet:

http://www.swean.com/jan2007/CompetentieRapport 20050708.doc.

Uhlenbrook, S.; de Jong, E. 2012. T-shaped competency profile for water professionals of the future, Hydrology and Earth System Sciences 9(3): 2935-2957. http://dx.doi.org/10.5194/hessd-9-2935-2012

UNC Charlotte Course Catalogs. 2012-2013. Graduate catalog: the graduate school [online], [cited 11 February 2013]. Available from Internet:

http://catalog.uncc.edu/graduate-catalogs/current/grad uate-school.

University of Copenhagen. 2012. MSc programme in Landscape Architecture [online]. [cited 11 February 2013]. Available from Internet:

http://www.life.ku.dk/uddannelse/studerende/studieordni nger/Studieordninger_2008-09/MSc_Programme_in_La ndscape_Architecture.aspx.

University of Sydney. 2012. Urban \& Regional planning [online], [cited 11 February 2013]. Available from Internet:

http://sydney.edu.au/architecture/programs_of_study/ postgraduate/urban_regional_planning.shtml.

Urban Realm. 2011. Do we need architects? [cited 11 February 2013]. Available from Internet:

http://www.urbanrealm.com/features/319/Do_we_need_ architects $\% 3$ F.html.

Uttarakhand Board of Technical Education. 2009. Competency profile of diploma holders in Civil Engineering [online], [cited 11 February 2013]. Available from Internet: http://www.ubter.in/curriculum/civil/document/compat ancyprofile.pdf.

Virginia Jobs. 2012. Career guide for architects [online] [cited 11 February 2013]. Available from Internet: http://jobs.virginia.gov/careerguides/architects.htm.

Yeung, S. S. Y.; Lam, J. T. S.; Leung, A. W. L.; Lo, Y. C. 2012. Curriculum change and innovation. Hong Kong: Hong Kong University Press. 300 p.

Josifas PARASONIS. Professor, Doctor Habil. Vilnius Gediminas Technical University (VGTU), Sauletekio al. 11, Vilnius, Lithuania. PhD, Vilnius Civil Engineering Institute (VISI, now VGTU, 1973). Doctor Habil (technical sciences, NIIZB, Moscow, 1992). Professor, VGTU (1994). Head of Department of Architectural Engineering. Author of over 170 publications (research results and study guides). Research interests: reliability of structures and buildings; energy efficient and resource saving buildings, architecture and engineering interaction.

Andrej JODKO. PhD student in Architectural Engineering at Vilnius Gediminas Technical University. His principle research interests have focused on the interaction of architecture and engineering and the functional construction of buildings, as well as issues in architectural engineering education, which he has explored in his articles that have been published in various Lithuanian architecture journals. Prior to his PhD studies, he worked at a number of architecture firms in Lithuania. 